\title{
Effect of Cassava Peels and Palm Kernel Cake Meal Mixtures on the Heamatological and Serum Biochemical of Finisher Pigs
}

\author{
H. Moseri, E. N. Belonwu and C. Egieme
}

\begin{abstract}
The research was carried out for a period of twenty two (22) weeks at the Piggery unit of the Teaching and Research Farm of the Faculty of Agriculture, Ambrose Alli University, Ekpoma, Edo State, Nigeria. The objective of this study was to assess the effect of cassava peels and palm kernel cake (PKC) mixture at 1:1 ratio on haematological and serum biochemical of finisher pigs. Fourty (40) finisher pigs of large white breed were used for the study. Each group of finisher pigs contained eight pigs per treatment, were respectively allocated to five treatment diets in a completely randomized design (CRD). At the end of the twenty two (22) weeks feeding trial, ten pigs consisting of two pigs per treatment were randomly selected; animals were starved of feed for 12 hours before blood samples were collected from the two pigs each per treatment via the ear vein using a sterilized disposable syringe and needle. The parameters determined were red blood cells (RBC), haemoglobin (Hb), packed cell volume (PCV), white blood cell (WBC), total protein, albumin, globulin and serum cholesterol. This finding therefore recommended that cassava peels/pkc mixtures can successfully replace maize in finisher pigs ration without any adverse effect on the animals and consumers, since the haematological and serum biochemical parameters fell within normal values for pigs.
\end{abstract}

Index Terms - cassava peels, finisher pigs, haematology, serum biochemical.

\section{INTRODUCTION}

In identification of the prospect of pigs as inexhaustible and quick growing animal, as well as a good converter of feed to meat, many Nigerian farmers have engage upon intensive production of pigs. This endeavor will increase animal protein supply, at reduced cost for human consumption, if properly harnessed [5]. Pig production represents the fastest means of correcting animal protein shortage in Africa. Apart from their high rate of reproduction, poultry and pigs are characterized by the best efficiency of nutrient transformation into high quality protein (meat), although the cost of the transformation is very high, precisely in Nigeria [18]. Therefore, nutrient supply has to be with care in the manipulation, to ensure the production of meat at profitable rate. There exist in Nigeria some agro industrial by-products and crop residues that can be used as total or partial replacements for the conventional ingredients in livestock feeds. Pigs are capable of converting these agro-industrial by-products or 'wastes' of all kinds

Published on August 21, 2020.

H. Moseri, College of Education, Nigeria.

(e-mail: mosierihillary ${ }^{\circledR}$ gmail.com)

E. N. Belonwu, College of Education, Nigeria

C. Egieme, College of Education, Nigeria. discarded by humans into healthy animal protein useful to the human being. A caution evaluation of this product derived from the animal's for human consumption is very pertinent to ascertain the health status of the end users, which is of paramount interest. However, the major means of assessment is through the haematology and serum biochemical of the animal. [6] stressed that when haematological values fall within the normal range established for the animal, it is an indication that diets did not show any adverse effect during the experimental period. [11] Stated that the haematological components are valuable in monitoring feed toxicity especially with feed constituents that affect the blood as well as the health status of farm animal. [15] and [16] posited that haematological parameters are used in routine screening for the health and physiological status of livestock and even humans. [3] Documented that haematological traits especially PCV and $\mathrm{Hb}$ were correlated with the nutritional status of animals PCV and other haematological parameters are useful aids to prognosis and may reveal adverse condition even when the animal did not display obvious clinical signs of ill health [4]. This study therefore, evaluated the effect of cassava peels and palm kernel cake mixtures on the haematological and serum biochemical parameters of finisher pigs.

\section{MATERIALS AND METHODS}

\section{A. Experimental Site}

The research was carried out at the Piggery unit of the Teaching and Research Farm of the Faculty of Agriculture, Ambrose Alli University, Ekpoma. The farm is located in Esan West Local Government Area of Edo State, Nigeria; which is characterized with an annual rainfall of 1500$2000 \mathrm{~mm}$ per annum. Relative humidity is about $75 \%$ with temperature average of $32^{\circ} \mathrm{C}$.

\section{B. Experimental Animals and Design}

The research was carried out for a period of twenty two weeks. A total of 40 finisher pigs of large white breed were used for the study. The pigs were divided into 5 groups with 8 pigs each per replicate. Each group of finisher pigs were respectively allocated to five treatment diets in a Completely Randomized Design (CRD).

\section{Management of Experimental Animals}

Pigs were fed twice daily and water supplied adlibitium. The treatment diets were formulated with cassava peels/Pkc included at 0, 25, 50, 75 and $100 \%$ levels of replacement of maize in the diets. The 1:1 ratio of cassava peels and palm 
kernel cake was derived by weighing equal quantities $(\mathrm{kg})$ of the two test ingredients using a manual scale. All the diets were formulated to be iso-nitrogenous and iso-caloric (Table 1).

\section{Haematological Studies}

At the end of twenty two weeks feeding phase, the animals were starved of feed for 12 hours before blood samples were collected from two pigs per treatment each, from the ear vein using a sterilized disposable syringe and needle. Prior to bleeding, a cotton swab soaked in $70 \%$ ethanol was used to dilate the ear vein and to prevent infection or contamination of the blood sample. A $5.0 \mathrm{ml}$ blood was collected from each pig into labeled sterile universal bottles containing Ethylene-Diamine-Tetra-Acetic acid (EDTA) as anticoagulant. This was used to determine the red blood cells (RBC), hemoglobin $(\mathrm{Hb})$, packed cell volume (PCV), white blood cell (WBC). Another $5.0 \mathrm{ml}$ of blood was collected into labeled sterile sample bottles without anticoagulant and used to determine the biochemical components viz. total protein, albumin, globulin and serum cholesterol according to [7].

\section{E. Statistical Analysis}

All data collected were analyzed using [14] package and differences in treatment means were separated using Duncan's Multiple Range Test [8] as outlined by [12].

TABLE I: COMPOSITION OF EXPERIMENTAL DiETS FoR FINISHER PIGS

\begin{tabular}{llllll}
\multicolumn{5}{c}{$(\mathrm{G} / 100 \mathrm{KG})$} & \\
\hline Ingredients & $\mathbf{0}$ & $\mathbf{2 5 \%}$ & $\mathbf{5 0 \%}$ & $\mathbf{7 5 \%}$ & $\mathbf{1 0 0 \%}$ \\
& & & & & \\
\hline Maize & 40.00 & 30.00 & 20.00 & 10.00 & - \\
Cassava & - & 10.00 & 20.00 & 30.00 & 40.00 \\
peels/PKC & & & & & \\
Ground Nut & 18.87 & 20.00 & 21.13 & 22.28 & 23.42 \\
Cake & & & & & \\
Wheat Offal & 35.83 & 33.70 & 32.37 & 31.02 & 29.68 \\
Bone Meal & 1.50 & 1.50 & 1.50 & 1.50 & 1.50 \\
Limestone & 2.00 & 2.00 & 2.00 & 2.00 & 2.00 \\
Palm Oil & 1.00 & 2.00 & 2.20 & 2.40 & 2.60 \\
Finisher & 0.25 & 0.25 & 0.25 & 0.25 & 0.25 \\
Premix* & & & & & \\
Salt & 0.35 & 0.35 & 0.35 & 0.35 & 0.35 \\
Ronozyme** & 0.20 & 0.20 & 0.20 & 0.20 & 0.20 \\
\hline Total & $\mathbf{1 0 0 . 0 0}$ & $\mathbf{1 0 0 . 0 0}$ & $\mathbf{1 0 0 . 0 0}$ & $\mathbf{1 0 0 . 0 0}$ & $\mathbf{1 0 0 . 0 0}$ \\
Calculated & & & & & \\
Analysis: & & & & & \\
Crude Protein & $\mathbf{1 7 . 8 1}$ & $\mathbf{1 7 . 7 5}$ & $\mathbf{1 7 . 8 5}$ & $\mathbf{1 7 . 9 0}$ & $\mathbf{1 7 . 9 6}$ \\
(\%) & & & & & \\
ME(Kcal/Kg) & $\mathbf{2 8 3 2 . 6 6}$ & $\mathbf{2 8 1 7 . 9 4}$ & $\mathbf{2 8 0 1 . 3 8}$ & $\mathbf{2 8 3 3 . 3 2}$ & $\mathbf{2 8 6 6 . 2 5}$ \\
Fat (\%) & 4.58 & 6.20 & 7.8 & 9.44 & 11.09 \\
Fibre (\%) & 5.03 & 6.66 & 8.28 & 9.98 & 11.51 \\
Ash (\%) & 5.91 & 9.01 & 12.11 & 15.30 & 18.53 \\
Calcium (\%) & 0.80 & 0.80 & 0.80 & 0.80 & 0.80 \\
Starch (\%) & 41.00 & 37.79 & 34.58 & 31.34 & 28.08 \\
\hline$\quad$ Vity & & & & \\
\hline
\end{tabular}

*Vitamin-mineral premix/kg diet: Vitamin A-8,000 IU, Vitamins D3 3,000 IU, Vitamins E-8 IU, Vitamin K -2mg, Vitamin B1- $1 \mathrm{mg}$, Vitamin B2-0.2 mg, Vitamin B12-5 mg, Nicotinamide $-10 \mathrm{mg}$, Selenium- $0.1 \mathrm{mg}$, Ca Pantothenate $-5 \mathrm{mg}$, Folic acid $-0.5 \mathrm{mg}$, Choline Chloride $-150 \mathrm{mg}$, Iron $-20 \mathrm{mg}$, Manganese $-80 \mathrm{mg}$, Copper $-8 \mathrm{mg}$, Zinc $-50 \mathrm{mg}$, Cobalt $0.225 \mathrm{mg}$, Iodine $-2 \mathrm{mg}$ Antioxidant $-0.1 \mathrm{ppm}$ Key:- CPM $=$ Cassava peels meal, $\mathrm{PKC}=$ Palm kernel cake, $\mathrm{GNC}=$ Groundnut cake, C.P. $=$ Crude protein, $\mathrm{ME}=$ Metabolizable energy.

**Ronozyme Composition of the product, sodium sulfate (52.7\%), calcium carbonate $(15 \%)$, kaolin $(9 \%)$, dextrin and sucrose $(8 \%)$, cellulose $(6 \%)$ and vegetable oil (7\%).

\section{RESULTS}

Haematological parameters assessed in finisher pigs as influenced by the experimental diets in Table 2. Results obtained shows a significant $(\mathrm{P}<0.05)$ differences among values recorded for the experimental finisher pigs except RBC. PCV was higher in $25 \%$ diet followed by $75,50,100$ and $0 \%$ diets with corresponding values of 40.62, 40.55, 37.65 , and $36.45(\%)$ respectively. Red blood cell ( $\mathrm{RBCx} 10$ $6 / \mathrm{ml}$ ) values of $6.19,6.18,5.87,6.24$ and 5.82 were obtained for finisher pigs fed diets containing $0,25,50,75$, and 100 (\%) respectively. WBC values ranged from 40.63 to $36.45 \times 10^{-3} / \mathrm{ml}$ from diet 2 to 1 . Haemoglobin was higher in $25 \%(13.90 \mathrm{~g} / \mathrm{dl})$ than on diets $75(13.20), 50(12.40), 0$ $(12.25)$ and $100 \%(12.20 \mathrm{~g} / \mathrm{dl})$. Mean corpuscular volume $(\mathrm{MCV})$ was significantly $(\mathrm{P}<0.05)$ affected by the diets with the numerical values of $58.90,64.15,64.80,64.85$ and 65.4 $(\mathrm{g} / \mathrm{dl})$ for diet $0,50,100,75$ and $25(\%)$ correspondingly. $\mathrm{MCH}$ values of $16.65,18.35,18.28,17.65$ and 18.35 (pg) were for diet 1, 2, 3, 4 and 5 respectively. MCHC values ranged from $28.05 \%$ of diet 3 to $27.65 \%$ of diet 4 . Lymphocytes values was higher in control $(0 \%)$, followed by $25,50,75$, and $100 \%$ cassava peels/Pkc diet, with corresponding values of $91.55,63.75,69.45,69.00$, and $68.30(\%)$. Serum and biochemical parameters of total protein, albumin, globulin, Creatinine, urea, cholesterol, calcium and phosphorous indicated significant $(\mathrm{P}<0.05)$ differences in Table 3. Total protein value of $8.70 \mathrm{~g} / \mathrm{dl}$ was highest at $0 \%$, than on diet 100 (8.15), 25 (8.00), 50 (7.40) and $75 \%(7.25 \mathrm{~g} / \mathrm{dl})$. Albumin diets of $0,25,50,75$ and 100 $\%$ with values of $5.25,4.10,4.00,3.75$ and $4.05 \mathrm{~g} / \mathrm{dl}$ respectively. Globumin values of $3.45,3.90,3.40,3.50$ and $4.10 \mathrm{~g} / \mathrm{dl}$ for diets $0,25,50,75$ and $100 \%$ respectively. Creatinine values of $1.85,1.25,1.15,1.30$ and $1.65 \mathrm{~g} / \mathrm{dl}$ with urea values of $46.00,43.00,48.50,48.40$, and $64.50 \mathrm{~g} / \mathrm{dl}$ for diets $0,25,50,75$ and $100 \%$ in that order. Cholesterol values ranged from 103.00 in diet $100 \%$ to $76.50 \mathrm{mg} / \mathrm{dl}$ of diet $0 \%$. Calcium values of $9.05,9.15,8.85,8.75$ and 8.55 $\mathrm{g} / \mathrm{dl}$ for diets $0,25,50,75$ and $100 \%$. Phosphorus numerical values of $6.55,6.70,6.45,6.50$ and $5.70(\mathrm{mmol} / \mathrm{l})$ for diets $0,25,50,75$ and $100 \%$ respectively.

TABLE II: HaEmatological PARAMETERs OF Finisher Pigs Fed DiETs CONTAINING DIFFERENT LEVELS OF CASSAVA PEELS/PKC

\begin{tabular}{|c|c|c|c|c|c|c|}
\hline \multirow[b]{3}{*}{ Parameters } & \multicolumn{5}{|c|}{ MIXTURES } & \\
\hline & $\mathbf{0}$ & 25 & 50 & 75 & 100 & \\
\hline & 1 & 2 & 3 & 4 & 5 & $\begin{array}{r}\text { SEM } \\
( \pm) \\
\end{array}$ \\
\hline $\mathrm{PCV}(\%)$ & $36.45^{\mathrm{b}}$ & $40.62^{\mathrm{a}}$ & $37.65^{b}$ & $40.55^{\mathrm{a}}$ & $37.65^{\mathrm{b}}$ & 1.26 \\
\hline $\begin{array}{l}\mathrm{RBC}\left(\mathrm{x} 10^{-6}\right. \\
/ \mathrm{ml})\end{array}$ & 6.19 & 6.18 & 5.87 & 6.24 & 5.82 & 0.01 \\
\hline $\begin{array}{l}\text { WBC (x } 10^{-} \\
3 / \mathrm{ml})\end{array}$ & $36.45^{\mathrm{b}}$ & $40.63^{\mathrm{a}}$ & $37.65^{\mathrm{b}}$ & $40.55^{\mathrm{a}}$ & $37.65^{\mathrm{b}}$ & 1.27 \\
\hline $\mathrm{Hb}(\mathrm{g} / \mathrm{dl})$ & $12.25^{\mathrm{b}}$ & $13.90^{\mathrm{a}}$ & $12.40^{\mathrm{b}}$ & $13.20^{\mathrm{ab}}$ & $12.20^{\mathrm{b}}$ & 0.60 \\
\hline $\operatorname{MCV}(\mathrm{g} / \mathrm{dl})$ & $58.90^{\mathrm{b}}$ & $65.40^{\mathrm{a}}$ & $64.15^{\mathrm{a}}$ & $64.85^{\mathrm{a}}$ & $64.80^{\mathrm{a}}$ & 0.94 \\
\hline $\mathrm{MCH}(\mathrm{pg})$ & $16.65^{\mathrm{b}}$ & $18.35^{\mathrm{a}}$ & $18.28^{\mathrm{a}}$ & $17.65^{\mathrm{a}}$ & $18.35^{\mathrm{a}}$ & 0.42 \\
\hline $\mathrm{MCHC}(\%)$ & $28.20^{\mathrm{a}}$ & $28.05^{\mathrm{a}}$ & $28.50^{\mathrm{a}}$ & $27.65^{\mathrm{b}}$ & $28.35^{\mathrm{a}}$ & 0.35 \\
\hline $\begin{array}{l}\text { Lymphocytes } \\
\text { (\%) }\end{array}$ & $91.55^{\mathrm{a}}$ & $63.75^{\mathrm{b}}$ & $69.45^{\mathrm{b}}$ & $69.00^{\mathrm{b}}$ & $68.30^{\mathrm{b}}$ & 0.32 \\
\hline
\end{tabular}

a,b,c,d,e means along the same row with different superscripts are significantly $(\mathrm{P}<0.05)$ different from each other, SEM: Standard error of mean. 
TABLE III: SERUM BIOCHEMICAL PARAMETERS OF FINISHER PIGS FED DIETS CONTAINING DIFFERENT LEVELS OF CASSAVA PEELS/PKC MIXTURES

\begin{tabular}{|c|c|c|c|c|c|c|}
\hline \multicolumn{7}{|c|}{ levels of Inclusion (\%) } \\
\hline \multirow[b]{2}{*}{ Parameters } & \multirow{2}{*}{$\begin{array}{l}0 \\
1\end{array}$} & \multirow{2}{*}{25} & \multirow{2}{*}{$\begin{array}{l}\mathbf{5 0} \\
\mathbf{3}\end{array}$} & \multirow{2}{*}{$\begin{array}{l}75 \\
4\end{array}$} & \multicolumn{2}{|l|}{100} \\
\hline & & & & & 5 & $\begin{array}{r}\text { SEM } \\
( \pm) \\
\end{array}$ \\
\hline $\begin{array}{l}\text { Total Protein } \\
(\mathrm{g} / \mathrm{dl})\end{array}$ & $8.70^{\mathrm{a}}$ & $8.00^{\mathrm{a}}$ & $7.40^{\mathrm{b}}$ & $7.25^{\mathrm{b}}$ & $8.15^{\mathrm{a}}$ & 0.25 \\
\hline $\begin{array}{l}\text { Albumin } \\
(\mathrm{g} / \mathrm{dl})\end{array}$ & $5.25^{\mathrm{a}}$ & $4.10^{\mathrm{ab}}$ & $4.00^{\mathrm{b}}$ & $3.75^{\mathrm{b}}$ & $4.05^{\mathrm{b}}$ & 0.54 \\
\hline $\begin{array}{l}\text { Globumin } \\
(\mathrm{g} / \mathrm{dl})\end{array}$ & $3.45^{\mathrm{b}}$ & $3.90^{\mathrm{ab}}$ & $3.40^{\mathrm{b}}$ & $3.50^{\mathrm{b}}$ & $4.10^{\mathrm{a}}$ & 0.23 \\
\hline $\begin{array}{l}\text { Creatinine } \\
(\mathrm{mg} / \mathrm{dl})\end{array}$ & $1.85^{\mathrm{a}}$ & $1.25^{\mathrm{c}}$ & $1.15^{\mathrm{d}}$ & $1.30^{\mathrm{c}}$ & $1.65^{\mathrm{b}}$ & 0.21 \\
\hline Urea $(\mathrm{mg} / \mathrm{dl})$ & $46.00^{\mathrm{b}}$ & $43.00^{\mathrm{b}}$ & $48.50^{\mathrm{b}}$ & $48.40^{\mathrm{b}}$ & $64.50^{\mathrm{a}}$ & 3.65 \\
\hline $\begin{array}{l}\text { cholesterol } \\
(\mathrm{mg} / \mathrm{dl})\end{array}$ & $76.50^{\mathrm{b}}$ & $90.00^{\mathrm{ab}}$ & $88.00^{\mathrm{ab}}$ & $79.00^{\mathrm{b}}$ & $103.00^{\mathrm{a}}$ & 7.70 \\
\hline $\begin{array}{l}\text { Calcium } \\
(\mathrm{g} / \mathrm{dl})\end{array}$ & $9.05^{\mathrm{a}}$ & $9.15^{\mathrm{a}}$ & $8.85^{\mathrm{ab}}$ & $8.75^{\mathrm{ab}}$ & $8.55^{\mathrm{b}}$ & 0.20 \\
\hline $\begin{array}{l}\text { Phosphorus } \\
(\mathrm{mmol} / \mathrm{l})\end{array}$ & $6.55^{\mathrm{a}}$ & $6.70^{\mathrm{a}}$ & $6.45^{\mathrm{a}}$ & $6.50^{\mathrm{a}}$ & $5.70^{\mathrm{b}}$ & 0.27 \\
\hline
\end{tabular}

\section{DISCUSSION}

Packed cell volume $(\mathrm{PCV})$ significantly $(\mathrm{P}<0.05)$ differed among the experimental diets, which measures the percentage composition of the blood cells in relation to other contents such as the plasma and food nutrient, which was therefore used to accessed the normal blood level in the animal, which aligned with [3] that documented that haematological traits especially PCV and $\mathrm{Hb}$ correlated with the nutritional status of animals. RBC shows no significant $(\mathrm{P}>0.05)$ differences among the experimental diets. However, results fell within the range for normal healthy of finisher pigs as reported by [1], which shows that the uses of cassava peels/pkc meal as a replacement for maize had no hurtful effect on the red blood cells (RBC) of the animal's, which was also in accordance with [6], that indicated experimental diets did not show any undesirable effect on the pigs during the experimental period. The values reported for $\mathrm{WBC}, \mathrm{Hb}, \mathrm{MCV}, \mathrm{MCH}$ and $\mathrm{MCHC}$ were all significantly $(\mathrm{p}<0.05)$ affected by the diets. WBC, MCV, $\mathrm{MCH}$ and $\mathrm{Hb}$ fed cassava peels/pkc diets at the levels of 25 , 50,75 and $100 \%$ compete auspiciously with those on maize diet and the fact that these values were within the standard range as reported by [10], [1] can be concluded that the diets were not in any way ruinous to the pigs.

Serum and biochemical parameters of total protein, albumin, globumin, creatinine, urea, total cholesterol, calcium and phosphorus indicated significant $(\mathrm{P}<0.05)$ differences on the diets. Total protein values did not follow any particular pattern. However, $25 \%$ and $100 \%$ values were significantly higher than other diets, which might be ascribed to balancing of the qualities of ingredients used in the diets, that indicated a higher value of total protein in the diet of pigs and better quality of the experimental feedstuff, which is in accordance with [9], [17] which opined that feed component affect blood constituents and therefore, provides a base in nutritional assessment to analyze the nutritional status of an animal. Albumin values fell within the recommended range for pigs. However, according to [13] and [17] that posited albumin is an important blood clothing factor due to its ability to prevent hemorrhage, thus the higher the values, the better it is for the pigs. Further opined that globulin in the blood is an indication of the ability of pigs to fight against diseases. [2], [17] that described both creatinine and urea as an indirect measure of protein utilization and accurate determination of creatinine clearance. Serum cholesterol values were within the range in the diets. It is paramount to note the possible nutritional and health importance associated with cassava peels/pkc meal rather than many hazards which were reported to be associated with the utilization of cassava peels/pkc in the past. This finding therefore agreed with that of [1] that position the uses of cassava and cassava by-products can successfully replace maize in finisher pigs feeding without any adverse effect on the animals and consumers. However, haematological and serum biochemical parameters were within recommended values for normal pigs.

\section{CONCLUSION}

This finding therefore, recommended that cassava peels/pkc mixtures can successfully replace maize in finisher pigs ration without any adverse effect on the animals and consumers, since the haematological and serum biochemical parameters fell within normal values for pigs. However, the study is in tandem with these authors [17], [1], [3].

\section{REFERENCES}

[1] A. O. K. Adesehinwa, O. O. Obi, B. A. Makanjuola, O. O. Oluwole, and Adesina, M. A. Growing Pigs Fed Cassava Peel Based Diet supplemented With or Without Farmazyme 3000 Proenx: Effect on growth, carcass and blood. African Journal Biotechnology, vol. 10 (14) pp 2791-2796. 2011.

[2] B. O. Eggum, Blood urea measurement as a technique for assessing protein quality British Journal of nutrition vol 24 pp 983-988. 1970

[3] N. N. Etim, M. E. Williams, G. E. Enyenihi, M. D. Udo, and E. E. A Offiong. Haematological parameters: indicators of the physiological status of farm animals. British Journal of Science vol. 10 (1) pp 33 45. 2013.

[4] J. I. Eze, J. I. Onunkwo, S. V. O. Shoyinka, F. K. Chah, A. A. Ngene, N. Okolinta, J. A. Nwanta .and I. W. Onyenwe, Haematological profiles of pigs raised under intensive management system in SouthEastern Nigeria. Nigerian Veterinary Journal vol. 31 (2) pp 115-123. 2010 .

[5] H. Moseri, S.O. Oboh and S.E. Okosun, Influence of dietary levels of cassava peels and palm kernel cake on the performance and cost benefits of weaner pigs. Journal of Agriculture and Food Environment vol. 5 (4) pp 62-69. 2018.

[6] V. A. Togun, and B. S. A. Oseni. Effect of low level inclusion of biscuit dust in broiler finisher diet apparently healthy Red Sokoto Goats. Proceedings of the International Journal Advanced Research of Biological Science. Vol. 3 (6) pp 198-208. 2007.

[7] A.O.A.C. Association of Official Analytical Chemist. official methods of analysis 17th edition. Washongton DC. 2000

[8] D. B. Duncan, Multiple Ranges and Multiple F-Test, Biometrics, 1955. pp 11:1-42.

[9] A.E. Harper, V.W. Rodwell and P.A. Mayers, Review of physiological chemistry $\left(17^{\text {th }}\right.$, Edition). Lang Medical California, 1979. Pp 60-81, 188-216.

[10] F. U. Igene, Essentials of Pigs Production in Nigeria J.L.G Publishers, Ibadan $1^{\text {st }}$ Edition, 2006. Pp 36-43.

[11] L.J. Isaac, G. Abah, B. Akpan, and I.U. Ekaette, Heamatological properties of different breeds and sexes of rabbits. Proceeding of the $18^{\text {th }}$ Annual Conference of Animal Science Association of Nigeria. Pp 30-33. 2013.

[12] I. U. Obi, Statistical methods of detecting differences between treatment means and research methodology issues in laboratory and field experiments, AP Express Publishing Company, Limited, 2002. Pp 13-19. 
[13] H. D. K. Robert, P. Grammer, A. Mayes, V.A. Aletor and A. Rodwell, Harger Biochemistry $3^{\text {rd }}$ Edition, Oxford University Press, 1993. Pp 665-763.

[14] Statistix. Statistics for windows manual. Copyright 1985-2003. Analytical software. Version 8.02003.

[15] S. O. Aro, and M. B. Akinmoegun, Haematology and red blood cell osmotic stability of pigs fed graded levels of fermented cassava peel based diets. Proceeding of $17^{\text {th }}$ Annual Conference of Animal Science Association of Nigeria (ASAN)) Pp. 152-153. 2012.

[16] S. O. Aro, F. F. Ogunwale and O. A. Falade, Blood viscosity of finisher cockerel fed dietary inclusions of fermented cassava tuber wastes. Proceeding of the 18th Annual Conference of Animal Science Association of Nigeria Pp. 74-77. 2013.

[17] C. Anayo, Biochemical and nutritional characteristics of african yam bean seeds (Sphenostylis stenocarpa) in diets for broiler chicken. Ph.D Thesis, Department of Animal Science, Ambrose Alli University EKpoma, Edo state Pp. 124-125. 2010.

[18] S. O. Oboh, Nutritionist view of waste wealth and endless search for animal feed raw materials. 54 $4^{\text {th }}$ inaugural lecture, Ambrose Alli University, Epkoma, Edo State, Nigeria, Pp 9-15. 2016. 